\title{
Membatik Shibori Bersama Siswi Kelas XI IPA MA Annajah
}

\author{
Nofisulastri*, Muhamad Sarifuddin, Siti Rabiatul Adawiyah, Intan Kusuma Wardani \\ Universitas Pendidikan Mandalika, JI. Pemuda No. 59 A, Mataram, 83125, Indonesia \\ Email Korespondensi: nofisulastri@ikipmataram.ac.id
}

\section{Diterima: Oktober 2020; Revisi: November 2020; Diterbitkan: November 2020}

\begin{abstract}
Abstrak
Tujuan akhir kegiatan ini adalah memberikan pelatihan dasar membatik shibori dengan motif ragam hias kreasi local untuk membantu perekonomian di masa pandemic covid-19. Metode pelaksanaan kegiatan ini memiliki lima tahap yaitu komunikasi; observasi dan legalisasi; strategi; eksekusi; dan evaluasi. Kegiatan dilaksanakan pada bulan september 2020 bertempat di MA Annajah Yayasan Pendidikan Al Halimy dan rumah komunitas Kagamacare NTB. Tahapan sosialisasi diikuti sebanyak 11 siswi kelas XI IPA dan selanjutnya diseleksi berdasarkan domisili sejumlah 6 orang, sedangkan prosesi pelatihan diikuti sejumlah 12 orang bersama mahasiswa perwakilan pengurus HMPS Biologi Undikma. Hasil kegiatan menunjukkan setiap peserta telah berhasil membatik teknik Shibori dengan teknik pelipatan dan pewarnaan berdasarkan kreasi sendiri berupa jilbab dan slayer. Berdasarkan hasil kegiatan dapat disimpulkan bahwa peserta pelatihan dapat mengimplementasikan teknik membatik shibori. Selain itu, respon yang diberikan sangat positif dan telah ikut serta ke dalam komunitas membatik yang telah disediakan.
\end{abstract}

Kata Kunci: batik; Shibori; MA Annajah

\section{Making Shibori Batik with Class XI IPA MA Annajah}

\begin{abstract}
The ultimate goal of this activity is to provide basic training in making shibori batik with local decorative motifs to help the economy during the Covid-19 pandemic. The method of implementing this activity has five stages, namely communication; observation and legalization; strategy; execution; and evaluation. The activity was carried out in September 2020 at the MA Annajah Al Halimy Education Foundation and the home of the Kagamacare NTB community. The socialization stage was attended by 11 students of class XI IPA and then selected based on the domicile of 6 people, while the training procession was attended by 12 people with representatives of Undikma Biology HMPS management. The results of the activity showed that each participant had succeeded in making Shibori batik techniques with folding and coloring techniques based on their own creations in the form of a veil and a slayer. Based on the results of the activity, it can be concluded that the training participants can implement the shibori batik technique. In addition, the response has been very positive and has participated in the batik community that has been provided.
\end{abstract}

Keywords: Batik; Shibori; MA Annajah

How to Cite: Nofisulastri, N., Sarifuddin, M., Adawiyah, S., \& Wardani, I. (2020). Membatik Shibori Bersama Siswi Kelas XI IPA MA Annajah. Lumbung Inovasi: Jurnal Pengabdian kepada Masyarakat, 5(2), 40-47. doi:https://doi.org/10.36312/linov.v5i2.464

d.

https://doi.org/10.36312/linov.v5i2.464

\section{PENDAHULUAN}

Sekolah MA Annajah sebagai lokasi sasaran mitra kegiatan merupakan salah satu lembaga pendidikan swasta di bawah naungan Departemen Agama NTB yang didirikan sejak tahun 1984 oleh yayasan pendidikan Al Halimy. Keberadaan sekolah ini terletak di desa Sesela kabupaten Lombok Barat dengan jumlah siswa 235 orang (sumber data 2019) memiliki 
rincian riwayat keluarga adalah bernotabene sebagian buruh bangunan dan petani dengan strata pendidikan orang tua adalah sekolah dasar (SD). Riwayat latar belakang keluarga tersebut adalah tantangan bagi keluarga besar yayasan pendidikan Al-Halimy termasuk para guru dalam rangka mencerdaskan kehidupan anak bangsa.

Kegiatan pengabdian ini merupakan kegiatan lanjutan dari kegiatan sebelumnya yang menemukan permasalah minimnya motivasi belajar karena kekurangan dana (Nofisulastri et al., 2014). Hal ini diperparah akibat gempa dan wabah virus covid-19. Selain itu diketemukan bahwa program pemerintah pasca gempa untuk instansi kependidikan setempat hanya berupa bantuan sarana prasarana dan penanganan psikologis saja sehingga menyebabkan minimnya pemberian keterampilan/skills yang menunjang kehidupan di masa depan.

Salah satu solusi yang dapat diterapkan dan sesuai dengan potensi local desa Sesela yang merupakam ikon desa seni Lombok Barat adalah membatik. Batik merupakan warisan budaya Indonesia yang kaya akan nilai kehidupan (Steelyana, 2012) dan memiliki makna filosofis yang harus dipelajari serta dilestarikan (Saddhono et al., 2014). Batik berdasarkan teknik pembuatan dibedakan menjadi tiga yaitu batik cap, batik tulis, dan batik jumputan (Irvan et al., 2020). Teknik jemputan adalah teknik membatik yang diterapkan dalam kegiatan pelatihan ini. Teknik jemputan dipilih karena dapat menghasilkan berbagai macam motif dengan cara sederhana dan tidak membutuhkan waktu yang lama. Batik jumputan di Jepang terkenal dengan sebutan Batik Shibori. Shibori adalah teknik pewarnaan kain dengan menciptakan motif dari lipatan yang sudah ada sejak abad ke-8 (Hedstrom, 2000).

Pemilihan batik shibori sebagai produk kegiatan ini juga didasari oleh posisi tim pelaksana yang saat ini tergabung dalam komunitas shibori yaitu Kagama NTB sehingga akan sangat membantu dalam pelaksanaan kegiatan. Selain itu, kelebihan batik shibori yang dilaksanakan ini adalah proses pembuatan batik shibori yang mudah, bahan yang mudah didapatkan dengan warna yang bisa terbuat dari limbah tanaman herbal yang terfermentasi, dan tidak memakan waktu yang lama. Maka hal ini sangat cocok menjadi pilihan bagi target sasaran untuk belajar keterampilan dan dapat menjadi pilihan untuk berwirausaha. Selain itu, kegiatan ini melatih sasaran target berkreasi membuat pola warna yang diinginkan sekaligus merupakan gambaran strategi keterampilan proses untuk melatih otak dalam menyusun dan membuat batik serta pelestarian budaya.

Penelitian dan pengabdian terkait batik shibori sudah banyak dilakukan di Indonesia. Hal ini menunjukkan bahwa masyarakat sudah mengenal dan memiliki ketertarikan mempelajari batik shibori. Hasil penelitian dan pengabdian menunjukkan bahwa eksplorasi teknik sibori yang beragam dapat menghasilkan beragam motif tradisional Indonesia (Maziyah et al., 2019; Suantara et al., 2018) serta aplikasi pada masyarakat menunjukkan respon yang positif karena dapat membantu perekonomian masyarakat (Yanti et al., 2020). Kegiatan pengabdian ini bertujuan untuk transfer ilmu dan membangkitkan kembali perekonomian warga pasca gempa dan wabah covid-19.

\section{METODE PELAKSANAAN}

Kegiatan pengabdian masyarakat ini terdiri dari tahap persiapan hingga pelaksanaan yang dilaksanakan pada 10 Agustus s/d 06 September 2020. Gambaran pelaksanaan kegiatan membatik shibori merupakan pengembangan dari Suantara et al. (2018) dan Fauzi et al. (2018), yaitu:

1. Komunikasi: pembicaraan dengan mitra terkait dengan hakikat pengabdian masyarakat sebagai bagian dari pelaksanaan Tri Darma Perguruan Tinggi. Dalam pada ini disampaikan tentang tujuan dan rencana pengabdian masyarakat, dan penegasan bahwa kegiatan akan dilaku-kan oleh dosen-dosen yang kapabel dan kompeten dengan materi terkait. Tahap ini dilalui dengan tahap survei dan observasi dengan keluaran berupa surat kesediaan mitra untuk menerima kegiatan pengabdian masyarakat;

2. Observasi dan legalisasi: pendataan tentang kondisi mitra, mengidentifikasi permasalahan mitra, merumuskan solusi dan menyusun proposal;

3. Strategi, menunjuk pada penyusunan: materi pelatihan dan teknik penyampaian, pembagian tugas, dan jadwal kegiatan;

4. Eksekusi, menunjuk pada pelaksanaan puncak pelatihan membatik; 
5. Evaluasi: mengkaji kegiatan yang telah dilaksanakan untuk mengetahui tingkat keberhasilan dikait-kan dengan ketepatan jadwal, proses dan hasil belajar target dan mutu keluaran (Nofisulastri et al., 2014).

Proses praktik membatik shibori dipandu oleh tim pelaksana/pengabdi dan dibagi dalam lima kelompok yaitu setiap kelompok beranggota 2-3 orang sebagai bentuk pemenuhan standar protokoler kesehatan. Setiap kelompok mendapatkan perlengkapan pendukung yang digunakan pada saat mengikuti tahapan pembuatan kain shibori menggunakan teknik Kanoko Shibori dan Kumo Shibori (Suantara et al., 2018).

Adapun teknik Kanoko Shibori ini disebut juga teknik celup ikat dimana beberapa bagian kain diikat menggunakan benang atau karet untuk mendapatkan motif yang diinginkan. Sedangkan teknik Kumo Shibori merupakan teknik batik kain lipat dan diikat secara berdekatan dan digunakan untuk membentuk lingkaran. Masing-masing bahan pewarnaan disediakan oleh tim pelaksana menggunakan bahan alami dari limbah tumbuhan herbal dengan mellaui proses ekstraksi, pemasakan dan fermentasi sehingga bisa dijadikan dasar pewarna pada makanan dan tekstil.

Pelaksanaan kegiatan Pengabdian kepada Masyarakat ini melibatkan beberapa sumber daya manusia dan beberapa tenaga lapangan dari komunitas shibori yang kapabel dan kompeten dalam bidangnya. Kualifikasi dari anggota Tim Pengabdian kepada Masyarakat meliputi: (1) Memiliki pengalaman dalam penguasaan biofermentasi limbah (2) memiliki pengalaman dalam teknik membatik, (2) telah melakukan ujicoba terlebih dahulu pada bahanbahan yang digunakan menggunakan metode sederhana, (3) memiliki kemampuan dalam penyuntingan dan editing video selama proses kegiatan, (4) memiliki kompetensi dibidang bahasa dan pariwisata yang mendukung dalam pemberian motivasi entrepreneurship (dikaitkan dibidang seni dan pariwisata), dan dibantu oleh empat mahasiswa yang telah telah mendapat sosialisasi serta latihan keterampilan dasar membatik terlebih dahulu oleh tenaga teknis komunitas shibori Kagama NTB.

\section{HASIL DAN PEMBAHASAN}

Gambaran umum pelaksanaan kegiatan pengabdian masyarakat pendampigan membatik Shibori meliputi tahapan persiapan, pelaksanaan dan evaluasi akhir. Pelaksanaan persiapan dilakuakan dengan mengkomunikasikan terlebih dahulu kepada tim sekaligus observasi dan penyiapan legalitas. Proses sosialisasi kepada siswi kelas XI IPA dilaksanakan dengan menerapkan protokoler kesehatan selama pandemik Covid (gambaran kegiatan disajikan pada Gambar 1-6). Tahapan presensi peserta meliputi penandatangan daftar hadir peserta dengan pemberian masker, pemakaian handsanitizer, dan handout materi sekaligus penentuan posisi duduk peserta. Sedangkan tahapan sosialisasi kegiatan dan tanyajawab dilaksanakan secara paralel diikuti sesi terakhir tanyajawab peserta sebagai akhir kegiatan sosialisasi.

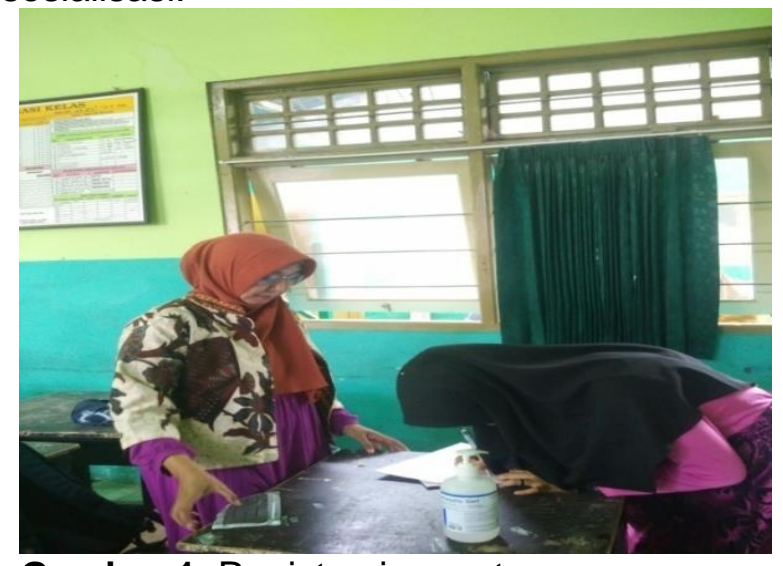

Gambar 1. Registrasi peserta

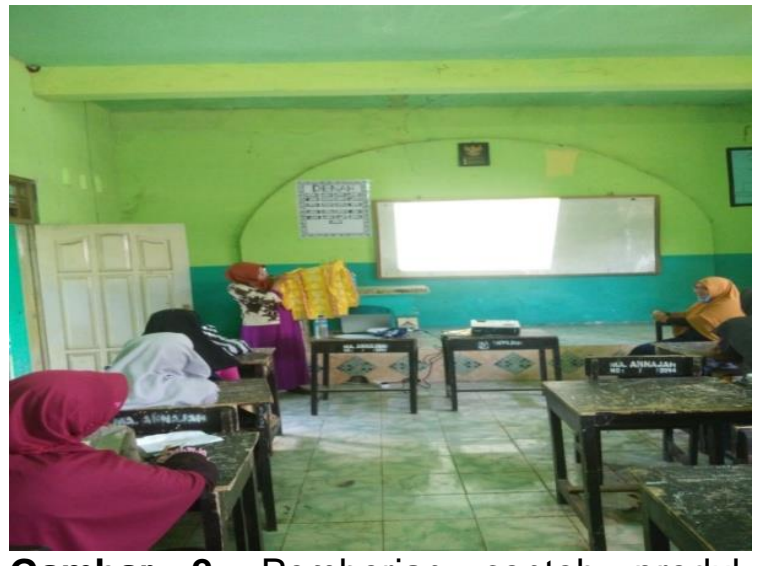

Gambar 2. Pemberian contoh produk membatik 


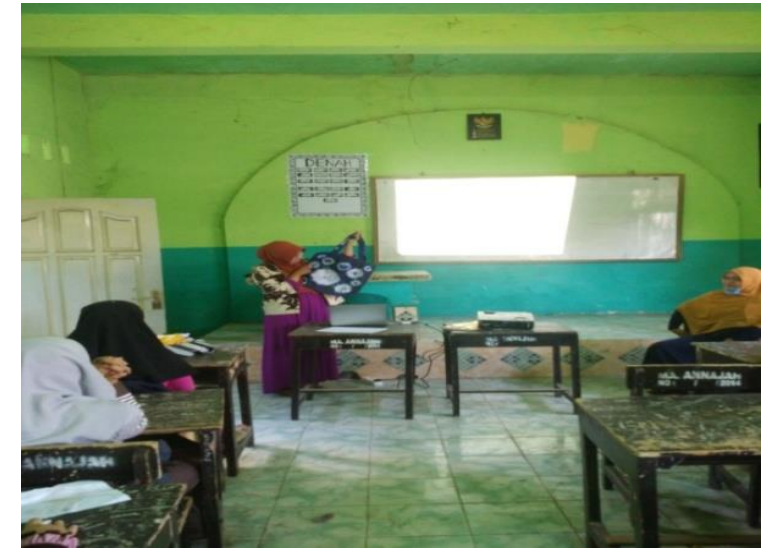

Gambar 3. Pemberian contoh produk membatik

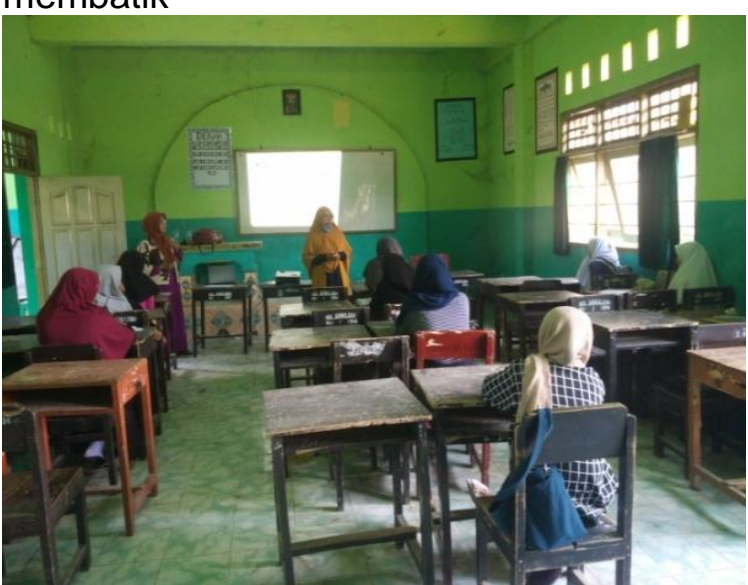

Gambar 5. Pemberian materi motivasi entreprener

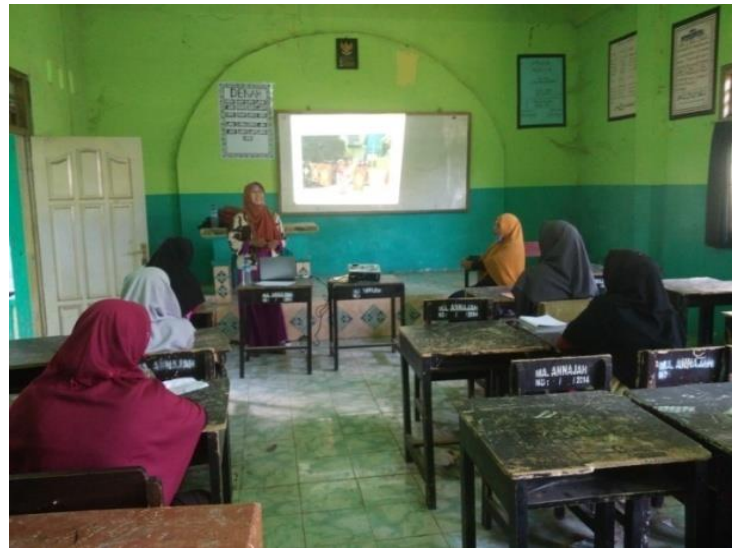

Gambar 4. Pemberian materi membatik shibori

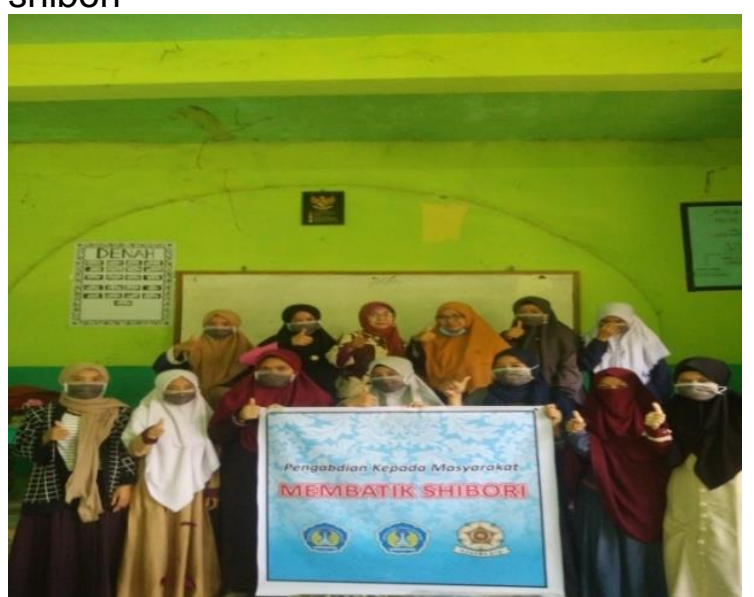

Gambar 6. Sesi pemotretan bersama peserta

Pelaksanaan pelatihan membatik shibori dilaksanakan selama dua hari di rumah Sekretariat Kagamacare NTB. Seperti halnya tahapan sosialisasi, kegiatan pelatihan juga menerapkan protokoler kesehatan di mana peserta wajib menggunakan masker, pemakaian handsanitizer, dan pengaturan duduk. Antusiasme peserta terlihat di mana peserta datang sebelum waktu yang ditetapkan dan beberapa membawa kain secara mandiri untuk mencoba membatik.

Tujuan dari pelatihan ini sejalan dengan pernyataan Saleh (2010) yaitu pemberian pengalaman kepada seseorang untuk mengembangkan tingkah laku (pengetahuan, keterampilan, sikap) agar mencapai sesuatu yang diinginkan yaitu membatik shibori. Prinsipprinsip pelatihan dalam kegiatan pengabdian ini merunut apa yang ditegaskan dalam Witjoro et al. (2019) yaitu 1) dilakukan dengan maksud untuk menguasai bahan pelajaran tertentu, melatih keterampilan dan penguasaan simbolsimbol rumus. Latihan tidak dilakukan terhadap pengertian/pemahaman, sikap dan penghargaan; 2) para peserta menyadari bahwa pelatihan itu bermakna bagi kehidupannya; dan 3) kegiatan pelatihan harus hidup, menarik, dan menyenangkan.

Pemberian materi teknik pembuatan batik shibori dilakukan oleh tim teknis menggunakan metode demonstrasi dan tanya jawab di mana setiap peserta telah dibagikan bahan-bahan dasar seperti kain, pengkait, stik, dan karet sembari mengikuti instruksi kerja. Tim teknis memberikan kesempatan untuk bertanya terkait teknik pelipatan dan pencelupan kain semabari tim memantau perkembangan keterampilan peserta. Gambaran prosesi pemberian materi dan pelatihan dasar membatik disajikan pada Gambar 7-14. 

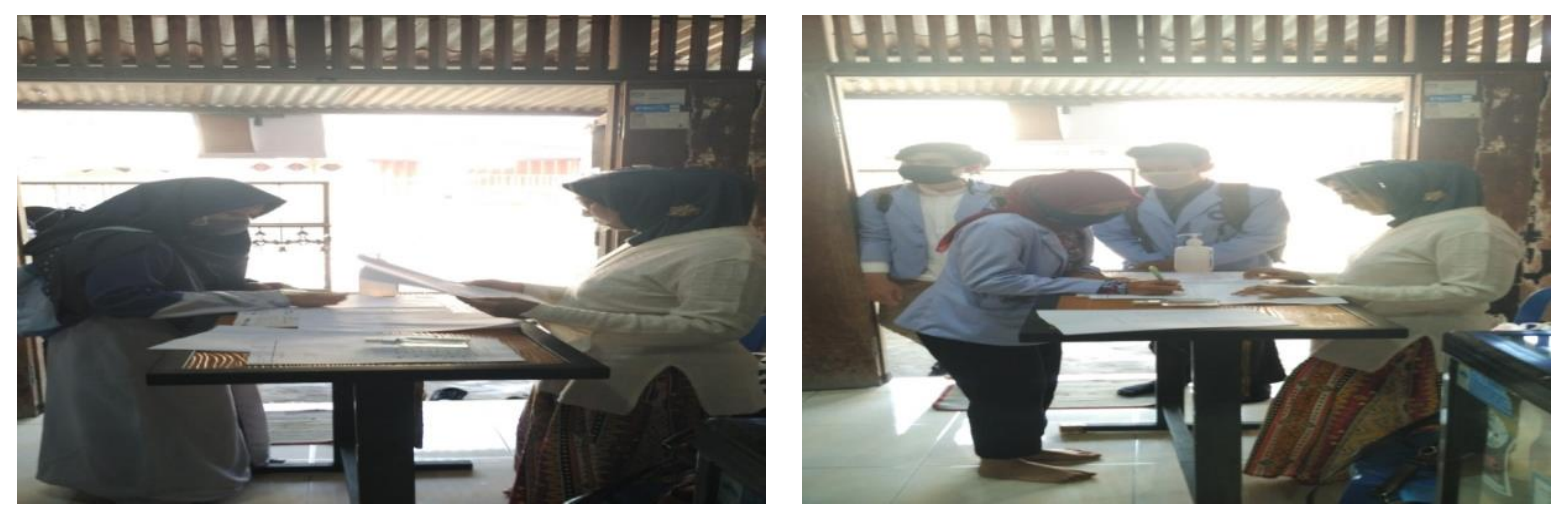

Gambar 7. Registrasi peserta siswi MA Gambar 8. Registrasi peserta HMPS Bio Annajah

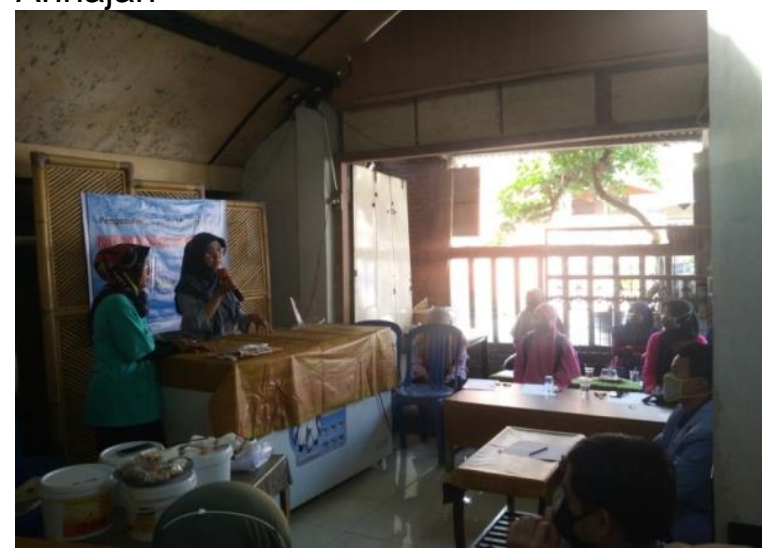

Gambar 9. Sambutan ketua pelaksana

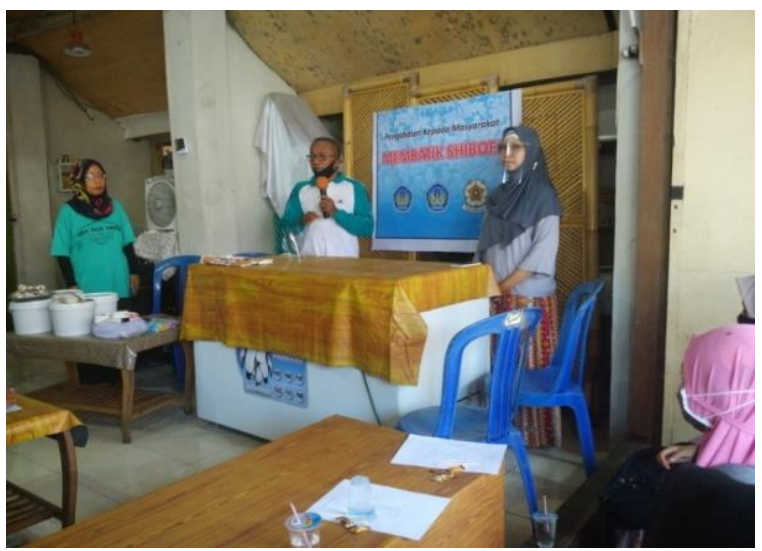

Gambar 10. Pemberian materi kegiatan

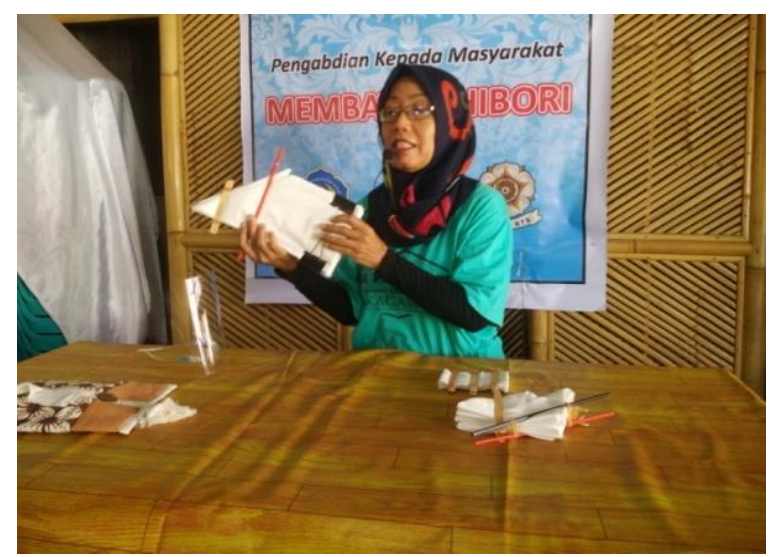

Gambar 11. Demonstrasi teknik melipat shibori

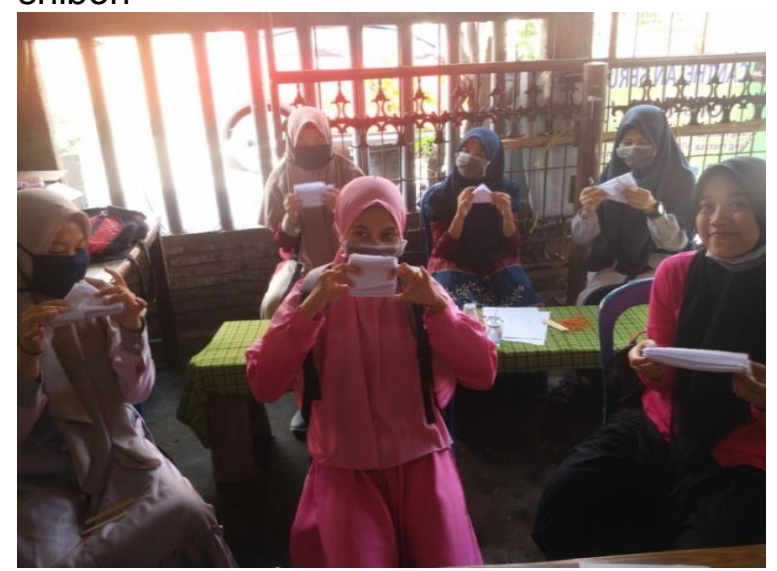

Gambar 13. Potret hasil melipat peserta bisnis

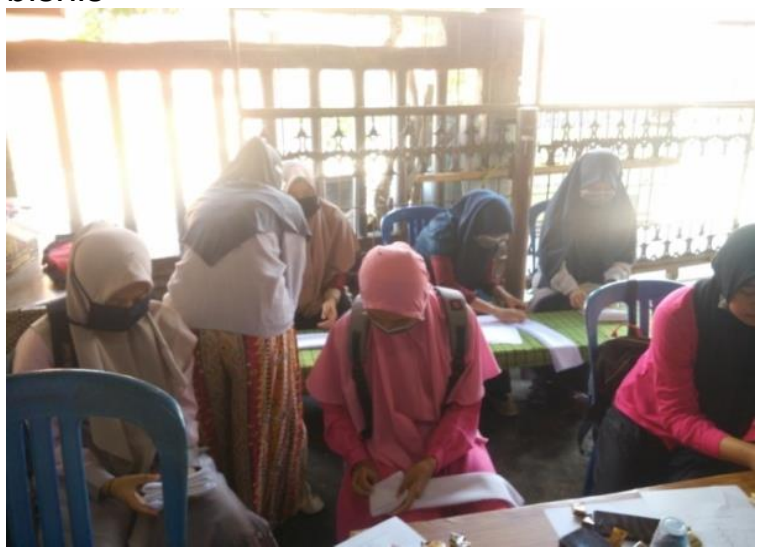

Gambar 12. Pendampingan teknik melipat

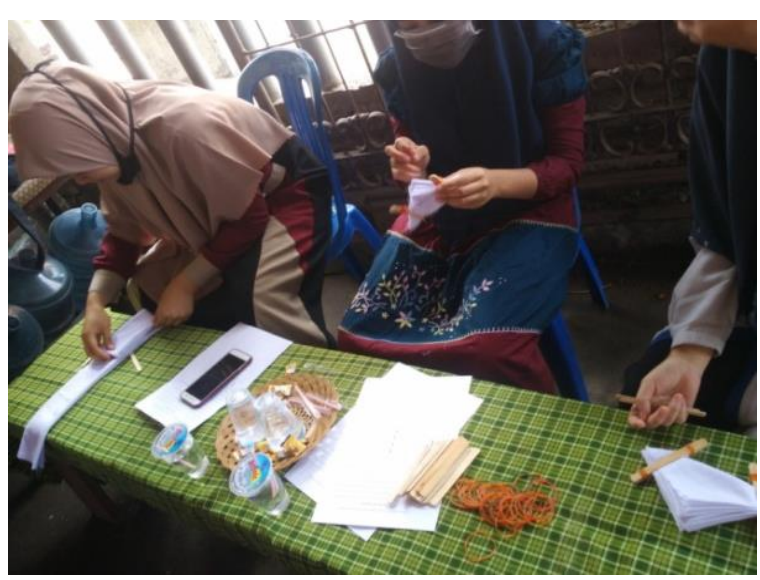

Gambar 14. Potret teknik penjepitan kain 
Tim pelaksana memberikan waktu peserta untuk menentukan teknik melipat dan final penjepitan kain sembari mempersiapkan bahan pencelupan nantinya. Dalam durasi 10 menit, peserta diberikan kesempatan untuk menentukan final dan titik warna yang dicelup sesuai keingginan masing-masing. Pendampingan selama prosesi pelipatan kain tetap dilakukan sebagai bentuk efisiensi waktu dan memastikan peserta telah mengerti/menguasai teknik pelipatan kain sebelum proses tahap membatik selanjutnya.

Proses pencelupan dasar dilakukan secara bergilir dengan 2 warna yang disiapkan adalah biru dan kuning, Sedangkan untuk pencelupan pewarnaan selanjutnya menggunakan warna tambahan yaitu merah muda, biru, hijau, dan oranye. Peserta secara mandiri melakukan pencelupan pewarnaan berdasarkan keinginan dengan teknik mencelup langsung ke wadah cat atau dengan teknik menuangkan secara perlahan-lahan. Tahap akhir dari pembuatan batik shibori adalah dengan melakukan pencucian dan penjemuran kain oleh peserta. Pencucian kain yang telah dijemur sebelumnya yang selanjutnya dilakukan penjemuran kembali guna finalisasi produk. Diakhir kegiatan oleh tim pelaksana dan teknis melakukan evaluasi untuk membahas hasil kegiatan dan strategi pendampingan selanjutnya. Keseluruhan kegiatan tahapan pewarnaan dan tahap penjemuran hingga evaluasi kegiatan ditunjukkan pada Gambar 15-22.

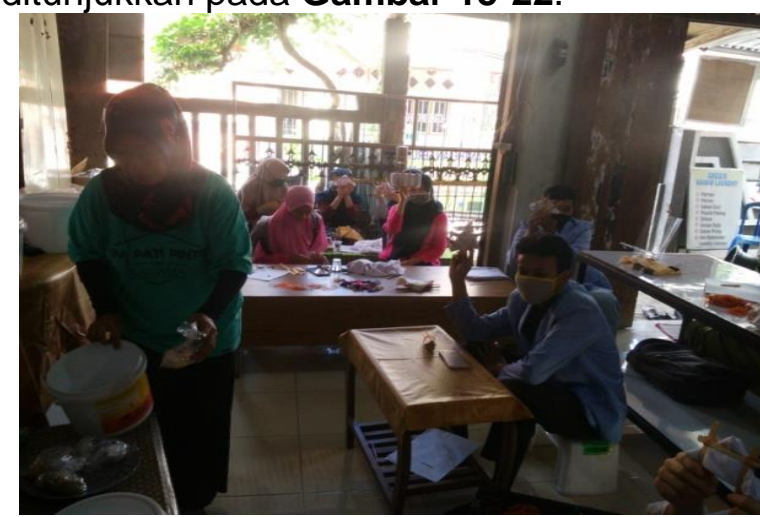

Gambar 15. Hasil final teknik lipat kain oleh peserta

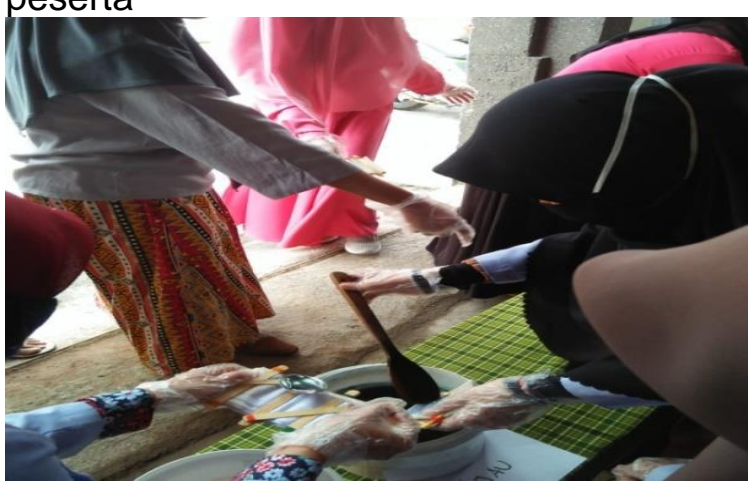

Gambar 17. Pencelupan kain masingmasing peserta

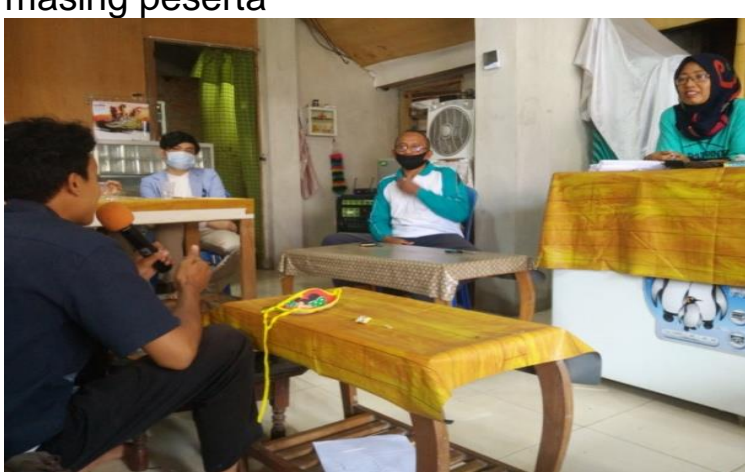

Gambar 19. Sesi tanya jawab peserta

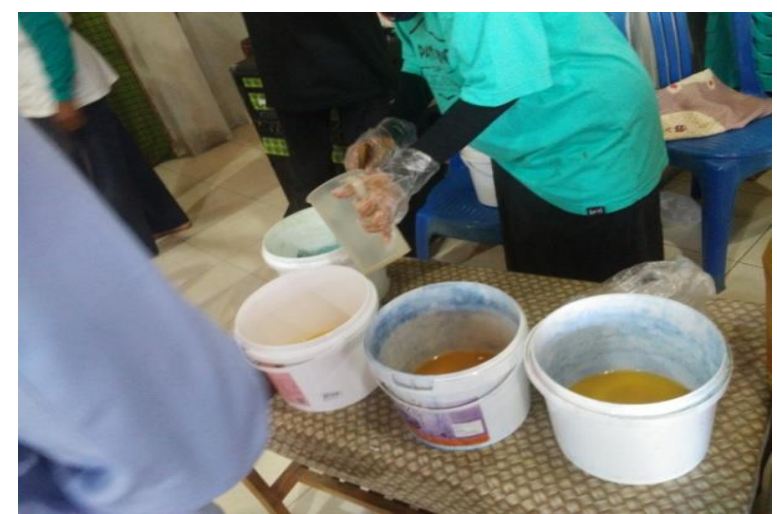

Gambar 16. Persiapan pewarnaan kain

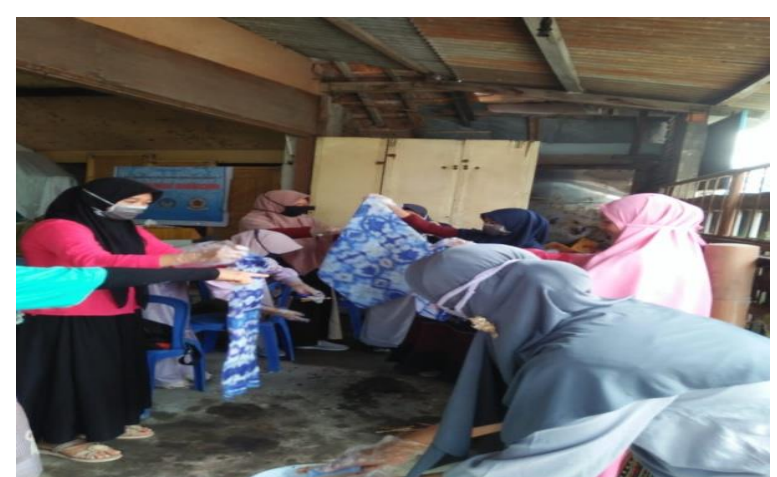

Gambar 18. Fiksasi kain setelah pencucian

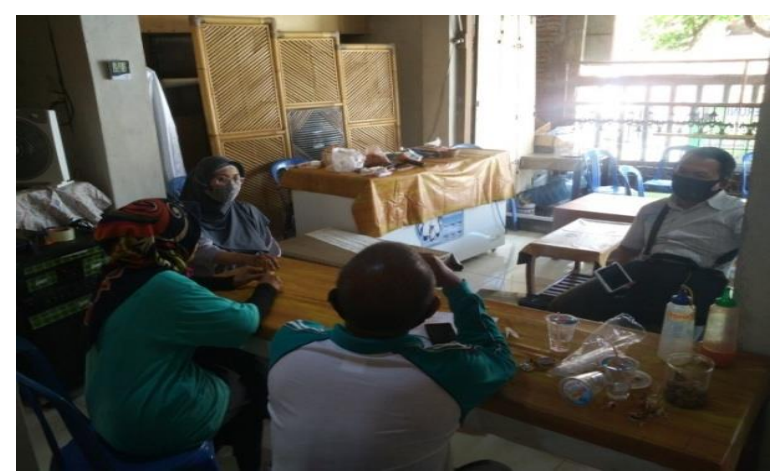

Gambar 20. Evaluasi dan diskusi kegiatan akhir 


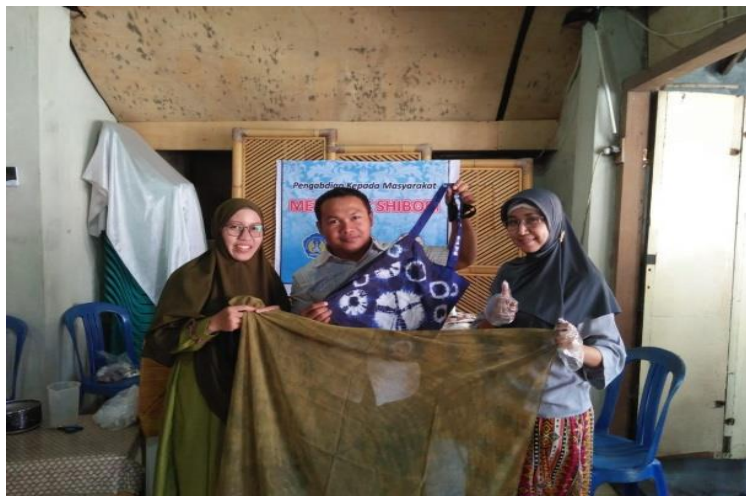

Gambar 21. Sesi potret hasil kreativitas tim

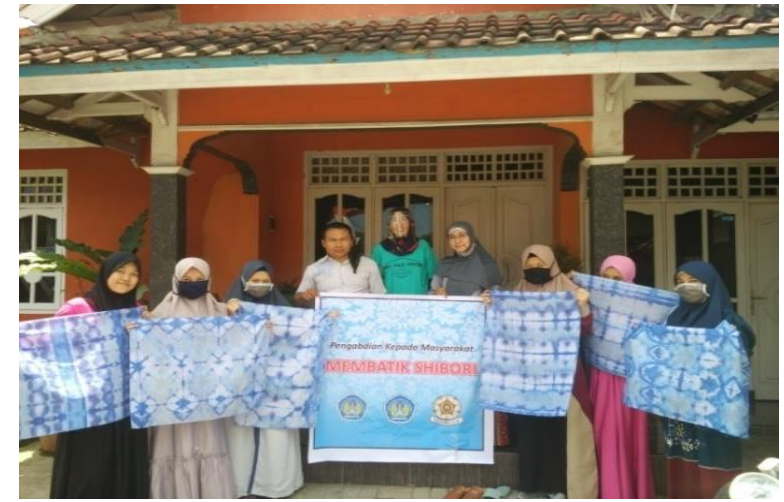

Gambar 22. Sesi potret hasil kreativitas peserta

Proses pembuatan batik shibori lebih cepat daripada batik lainnya dengan teknik pembuatannya yang sederhana, bahan dan alat yang mudah ditemukan (Kautsar, 2017). Lebih lanjut dijelaskan bahwa hasil dari batik shibori sangat menarik serta memiliki nilai jual yang tinggi (Amalia et al., 2020) serta proses pembuatan shibori diklaim mampu meningkatkan kemampuan motoric halus (Julianti \& Fatmawati, 2020) menyebakan kegiatan lebih menarik dan motivated bagi peserta.

\section{KESIMPULAN}

Berdasarkan respon kegiatan dan pengamatan disimpulkan bahwa kegiatan pelatihan membatik shibori dinyatakan sangat bermanfaat oleh peserta. Hal ini terlihat dari ketepatan waktu hadir peserta, kegiatan membuat beberapa modifikasi teknik melipat kain dan pencelupan warna, serta keingininan menjadi anggota komunitas shibori yang saat ini dikelola oleh Kagamacare NTB.

\section{SARAN}

Disarankan agar dilakukan pembinaan keterampilan membatik lebih lanjut seperti pada aspek teknik menggunakan beberapa teknik batik hasil kreativitas sendiri bahkan penggunaan bahan-bahan/alat pendukung lainnya. Untuk efektifitas pemberdayaan masyarakat ke depan, maka program pengabdian masyarakat perlu dilanjutkan secara berkala. Salahsatu solusi adalah pembuatan komunitas yang konsen terhadap peningkatan skills membatik dan pendampingan dalam pengelolaan dan pemasaran batik hasil kreasi. Pengembangan wawasan dan keterampilan secara kontinu dan benar-benar dibutuhkan oleh masyarakat dalam melestarikan dan mengembangkan seni batik dengan target akhir meningkatkan perekonomian perlu diperhatikan dan dilaksanakan pada masa mendatang.

\section{UCAPAN TERIMAKASIH}

Ucapan terima kasih kami sampaikan kepada tim teknis sekaligus instruktor kegiatan yaitu Ibu Nurhaeni, SS dan Bapak Waluyo Trisetyono yang telah menstransfer ilmu dan pengalaman terkait membatik shibori. Tidak lupa ucapan terimakasih kepad pihak sekolah MA Annajah yang telah memberikan kesempatan dan izin pendelegasian siswi kelas XI IPA untuk melakukan keseluruhan kegiatan.

\section{DAFTAR PUSTAKA}

Amalia, A., Izzhati, D. N., \& Mayasari, D. A. (2020). Pelatihan Pembuatan Produk Ekonomi Kreatif Kriya Tekstil dengan Teknik Shibori kepada Ibu-ibu Dawis Cempaka. ABDIMASKU: JURNAL PENGABDIAN MASYARAKAT, 3(2), 11. https://doi.org/10.33633/ja.v3i2.88

Fauzie, M., Kholisya, U., \& Wijayanto, C. S. (2018). Pelatihan Membatik untuk Anggota Majelis Taklim Salsabila Al Barokah di Lebak Jakarta Selatan. Jurnal PkM (Pengabdian kepada Masyarakat), 1(02), 143-150. https://doi.org/10.30998/jurnalpkm.v1i02.2545 
Hedstrom, A. (2000). Shibori: Tradition and Innovation. Textile Society of America Symposium Proceedings. https://digitalcommons.unl.edu/tsaconf/816

Irvan, M., IImi, A. M., Choliliyah, I., Nada, R. F., Isnaini, S. L., \& Khorinah, S. A. (2020). Pembuatan Batik Shibori Untuk Meningkatkan Kreativitas Masyarakat Pada Masa Pandemi Covid-19. Jurnal Graha Pengabdian, 2(3), 223-232.

Julianti, E., \& Fatmawati, F. (2020). Shibori Skills To Improve Fine Motor Ability For Children With Autism. Jurnal Penelitian Dan Pengembangan Pendidikan Luar Biasa, 6(2).

Kautsar, D. S. (2017). Eksplorasi Teknik Shibori pada Pakaian Ready To Wear. E-Proceeding of Art \& Design, 4, 905-920.

Maziyah, Si., Indrahti, S., \& Alamsyah, A. (2019). Implementasi Shibori Di Indonesia. KIRYOKU, 3(4), 214-220. https://doi.org/10.14710/kiryoku.v3i4.214-220

Nofisulastri, Primawati, S., \& Jannah, H. (2014). Pembinaan Pembuatan Mie Kering SABU di Desa Jenggik Utara Kabupaten Lombok Timur [Laporan Akhir Kegiatan Pengabdian Masyarakat DP2M DIKTI]. IKIP Mataram.

Saddhono, K., Widodo, S. T., Al-Makmun, M. T., \& Tozu, M. (2014). The Study of Philosophical Meaning of Batik and Kimono Motifs to Foster Collaborative Creative Industry. Asian Social Science, 10(9), p52. https://doi.org/10.5539/ass.v10n9p52

Saleh, M., H. ,. M. (2010). Pendidikan Nonformal (Dimensi dalam Keaksaraan Fungsional, Pelatihan, dan Andragogi). Remaja Rosdakarya.

Steelyana, E. (2012). Batik, A Beautiful Cultural Heritage that Preserve Culture and Supporteconomic Development in Indonesia. Binus Business Review, 3(1), 116. https://doi.org/10.21512/bbr.v3i1.1288

Suantara, D., Oktaviani, E., \& Siregar, Y. (2018). Eksplorasi Teknik Shibori Dalam Pengembangan Desain Motif Tradisional Indonesia Pada Permukaan Kain Sandang. Arena Tekstil, 32(2). https://doi.org/10.31266/at.v32i2.3304

Witjoro, A., Sari, M. S., Lestari, S. R., Irawati, M. H., Mahanal, S., Rohman, F., Prabaningtyas, S., \& Maslikah, S. I. (2019). Pemberian Pelatihan Membuat Batik Jumputan kepada Ibu PKK untuk Upaya Pelestarian dan Meningkatkan Ekonomi Masyarakat di Lowokwaru. Jurnal KARINOV, 2(2), 75-80. https://doi.org/10.17977/um045v2i2p75-80

Yanti, H. K., Paramita, V., Windyandari, A., Dwimawanti, I. H., Amalia, R., Dewi, A. L., Cahyaningsih, I. R., \& Pangestu, I. T. (2020). Pelatihan Pembuatan Batik Shibori Bagi Pengurus Daerah Wanita Islam Kota Semarang. Jurnal Pengabdian Vokasi, 1(3), 149152. 